C R Clement ${ }^{l}$ and $\Lambda M$ Reid $^{2}$

1 Geology Department, De Beers Consolidated Mines Limited, Kimberley

2 Department of Geology, University of Cape Town

\title{
INTRODUCTION
}

Synthesis of information from numerous occurrences indicates that kimberlite pipes are characterised by distinctive root, diatreme and crater zones. These zones are defined by specific contact and internal geological features and by differences in the nature of the infilling material (Hawthorne 1975, Clement, 1982). In this paper a theory of pipe formation is proposed which takes this geological complexity into account and stresses the important contributions of a number of interrelated, precursor, subsurface, genetic processes to the development of kimberlite pipes.

\section{ROOT ZONES}

A distinguishing feature of root (hypabyssal) zones is pronounced pipe irregularity in the form of: rapid changes in the dip and strike of contacts; 1ocal, low-angle, outward-dipping contacts; splitting of root zones into two or more discrete channels; blocky or serrated pipe contacts; pronounced elongation of the pipes or parts thereof along one or more preferred directions; non-vertical pipe axes; local transitions to partially dyke-like character; and subsurface dome-like or less regular appendages. This morphological irregularity of root zones is commonly related to joint set patterns and other discontinuities in the country rocks.

A second intrinsic feature of root zones is the occurrence of contact breccias which have been formed more or less in situ and consist of monolithological wall rock fragments with, or more commonly, without interstitial kimberlite. Explosion, intrusion and fluidisation breccias occur. Explosion breccias, devoid of kimberlitic material, are the most common form of contact breccia and occur primarily under overhangs (outward-dipping contacts) of country rock. Such contact breccias reach $50 \mathrm{~m}$ in width and some persist vertically for many tens of metres. They consist of angular fragments $(5-50 \mathrm{~cm})$ which have not been substantially displaced, as discrete breccia masses or relative to each other, after fragmentation. Minor slumping of the breccias may have occurred. Secondary minerals occur locally in voids between the breccia fragments. Fluidisation breccias also occur under overhangs and, similarly, have not been significantly displaced since their formation. They are kimberlitefree and consist (apart from minor secondary material) of locally derived wall rock. However, unlike explosion breccias, they consist predominantly of moderately to well-rounded "pebbles" or "cobbles". Intrusion breccias are relatively rare and reflect penetration of kimberlite magma along discontinuities in the wall rocks of pipes to produce country-rock/kimberlite "stockworks" of limited size (up to $30 \mathrm{~m}$ in width). Partial or complete detachment of angular wall rock blocks at contacts by magmatic intrusion is an associated feature.

Root zones are further characterised by complex internal geology. Commonly several (up to 20 plus) discrete kimberlite and kimberlite breccias (terminology of Clement, 1982; Clement and Skinner, in press), separated by sharp or gradational contacts, are present. Although they may differ considerably in respect of petrographic features such as texture, mineralogy and xenolith content and character these intrusions all reflect non-violent emplacement of kimberlite magma. Relatively slow crystallisation is indicated by commonly extensive and complex deuteric alteration of phenocrysts, by widespread, similarly complex, metasomatism of xenocrysts and crustal xenoliths by kimberlite magma/residual flutds and by the hypabyssal (subvolcanic) nature of the intrusions. Bulk composition determinations of these intrusions commonly indicate extremely high levels of volatile constituents relative to most other ultrabasic rocks.

\section{DIATREME ZONES}

Classical views of the nature of kimberlite pipes reflect the well known morpho- 
logical features of the diatreme zones. The main features of the latter are: regular shapes (inverted truncated cones); steep $\left(80^{\circ}-85^{\circ}\right)$ joint-bounded, smooth contacts (rare but in some instances extensive contact breccias do occur); vertical axes; and considerable vertical extent (up to $\sim 2 \mathrm{~km}$ ). Typically diatreme zones contain tuffisitic kimberlite breccias (Clement, 1982, Clement \& Skinner, in press) which consist of abundant, small (mainly microscopic to $5 \mathrm{~cm}$ across), angular, generally unaltered country rock xenoliths, complex assemblages of juvenile lapilli, mantle-derived xenoliths, discrete or broken kimberlite minerals and xenocrysts from mantle and crustal sources. These components are set in a matrix which consists in considerable part of minerals formed by vapour - phase crystallisation (or minerals which are the products of vapour condensates). Primary matrix mineralogical character is, however, commonly masked by extensive secondary alteration.

Huge down-rafted masses of country rock (floating reefs) commonly occur in peripheral locations in diatreme zones. Many of these masses are extensively brecciated, are devoid of kimberlite and closely resemble some root zone contact breccias (eg. kimberlite-free explosion breccias). Other floating reefs occur as competent down-rafted masses.

\section{CRATER ZONES}

Preserved examples of crater zones rarely exceed $300 \mathrm{~m}$ in depth. They are rudely circular and have relatively flat $\left(50^{\circ}-70^{\circ}\right)$ contacts. The surrounding wall rocks are commonly brecciated and the craters contain complex assemblages of pyroclastic and epiclastic kimberlite.

\section{MODEL OF FORMATION}

Root zone features - notably the complex morphology, the number, hypabyssal character, internal contact relationships and distribution (in relation to relative ages) of discrete intrusions (and contact breccias), the occurrence, at different stratigraphic levels, of contact breccias (commonly under overhangs that appear to be breached arches) and the presence of blind extensions (which may show several of the above features) - suggest that kimberlite pipes are initiated by intermittent, subsurface, upward-migrating processes. It is proposed that these processes lead eventually to irregular embryonic "pipes" that have developed upwards, from depths of $2-3 \mathrm{~km}$, to within $500 \mathrm{~m}$ of surface and are bounded by extensively brecciated wall rocks. Existing root zones are interpreted as remnants of such embryonic pipes.

It is considered that the genetic processes that are consistent with root zone features and are responsible for root zone (and hence embryonic pipe) formation and upward migration involve all or combinations of the following: hydraulic fracturing and wedging, magmatic stoping and intrusion brecciation, explosive and/or implosive brecciation, spalling, slumping and, possibly, rock bursting from temporarily free faces. Certain kimberlite-free contact breccias imply explosive brecciation resulting from the sequential release of $P \Delta V$ energy through the processes of second boiling and subsequent decompression, as proposed by Burnham (1985). Some similar breccias may reflect implosion of volatiles (previously rammed into the country rocks) due to pressure release caused, for example, by temporary withdrawal of magma. An additional possibility is that some kimberlite-free contact breccias reflect subsurface explosive interaction between rising magma and relatively deep, local, reservoirs of meteoric water. Such interaction seems unlikely, due to pressure constraints, at depths of $2-3 \mathrm{~km}$ below the paleosurface. It may, however, have occurred, in some instances, near the tops of embryonic pipes (in near-surface environments).

The original presence of extended root zones (embryonic pipes) is indicated by rare, preserved, contact breccias within diatreme zones, by the nature of brecciated floating reef masses (interpreted as detached, down-slumped, contact breccia), by transitional morphological relationships between diatreme and root zones, by the occurrence of breached arches at different (successive) levels in the root zone remnants of embryonic pipes, by transitions between diatreme facies and hypabyssal facies kimberlites and, less directly, by the shallow nature of crater zones. The upward extension of embryonic pipes is considered to be terminated by explosive outburst (formation of craters). Explosive breakthrough is probably accompanied by 
depressurisation-induced authigenic brecciation of the margins of the upper parts of embryonic pipes (extending and intensifying previously formed contact breccias).

The formation of diatreme zones is ascribed to the development, following explosive outburst, of vapour-liquid-solid fluidised systems. The fluids involved are believed to consist primarily of exsolved $\mathrm{CO}_{2}$ and $\mathrm{H}_{2} \mathrm{O}$, a situation consistent with the geochemical character of kimberlites. However, the fluidising fluids may be contaminated by meteoric water in many instances. Due to rapid depressurisation and attendant vapourisation and adiabatic expansion, these systems are believed to have evolved rapidly down embryonic pipes. Diatreme zones reflect the partial to complete incorporation, into these downward-migrating fluidised systems, of the breccia "envelopes" surrounding the embryonic pipe columns (plus other slumped or plucked country rock blocks and floating reefs). The diatreme zones thus contain complex assemblages of juvenile lapilli (autoliths, pelletal and less regularly-shaped lapilli) and xenolithic material. More or less regular-shaped diatreme conduits, commonly bounded by joint planes, are formed. The fluidisation events are considered to be short-lived and to wane rapidly from "lean-phase fluidisation" (capable of considerable pneumatic transport of solids) to "bubbling bed" (quiescent fluidised bed) systems, prior to rapid quenching.

Following the cessation of explosive outburst, the concomitant deposition of pyroclastic material and deflation accompanying final (interstitial) consolidation (vapour-phase crystallisation), cyclical deposition of epiclastic kimberlite (derived from ejectamenta surrounding the crater) occurs. An unresolved problem is the extent to which phreatomagmatic activity, resulting in pyroclastic outflow (base surge) and other pyroclastic deposits, plays a role in the formation of crater zones. Lorenz (pers. comm.) postulates that certain bedded units in the Orapa and Jwaneng craters (Botswana) are pyroclastic flows (probably base surge deposits). However, detailed studies which unambiguously confirm the occurrence of such material have not been undertaken at these (or other) localities. Phreatomagmatic activity may play a role in the development of the crater zones of kimberlite pipes. However, any theory which ascribes the formation of the pipes in toto primarily to this eruptive mechanism ignores (amongst other things); the genetic implications of the root zones, the petrographic nature of diatreme-facies kimberlite and the potential of magmas such as kimberlite to exsolve abundant juvenile volatiles on entering low-pressure regimes.

Irregularities in pipe morphologies and internal textural and mineralogical variations in part reflect multiple genetic events within major pipes. The genetic cycle outlined above may be repeated several (many) times, at varying intervals. Geological complexity may be further enhanced by interrupted (incomplete or aborted) or overlapping intrusive-explosive cycles and by variations in the nature, intensity, depth (relative to the paleosurface) and duration of specific formational/emplacement processes, during repeated cycles of subvolcanic-volcanic activity.

Secondary (post-volcanic activity) alteration, particularly along the diatreme contacts, results in volume adjustments (increases) within pipes. These volumetric increases cause slicken-siding along contacts and minor thrust faulting, particularly near surface, within the pipes.

\section{REFERENCES}

Burnham, C W, 1985. Economic Geology, 80, 6, 1515-1522.

Clement, C R, 1982. Unpublished Ph.D. Thesis, University of Cape Town.

Clement, C R and Skinner E M W. In Press. Geological Society of Southern Africa.

Hawthorne, J B, 1975. Physics and Chemistry of the Earth, 9, 1-15. Pergamon Press, Oxford. 